\title{
Rancang Bangun Tempat Tidur Pasien Otomatis Dengan Sensor Accelerometer Gyroscope Untuk Mengatur Keseimbangan Berbasis Mikrokontroler Arduino
}

\author{
Ogis Ockikiriyanto \\ Fakultas Teknik Program Studi Teknik Elektro Universitas Muhammadiyah Surabaya \\ Jl. Raya Sutorejo No. 59, Dukuh Sutorejo, Mulyorejo, Kota Surabaya, 60113 \\ e-mail : ogisocki46@gmail.com
}

Ir. Anang Widiantoro, S.T., M.T., IPM dan Dr. Eng Marwan Rosyadi, S.T., M. Eng

Dosen Pembimbing, Fakultas Teknik Program Studi Teknik Elektro Universitas Muhammadiyah Surabaya

\begin{abstract}
Abstrak- Tempat Tidur pasien Accelero Bed Control(ABC) adalah tempat tidur pasien yang memudahkan intansi rumah sakit agar menjaga kenyamanan pasien daan meningkatkan kualitas mutu rumah sakit. Tempat tidur ini bekerja pada jalur kemiringan rumah sakit. Tempat tidur pasien ini bekerja dengan menggunakan prinsip-prinsip motor DC untuk menaikan dan menurunkan tempat tidur,sensor accelerometer gyroscope untuk mendeteksi jalur kemiringan rumah sakit,relay,dan mikrokontroler arduino sebagai controler-nya. Metode yang digunakan untuk membuat alat ini adalah rancang bangun.Alat ini bekerja dengan pembacaan sensor accelerometer gyroscope untuk mendekteksi jalur kemiringan pada rumah sakit dan relay sebagai driver untuk menggerakaan motor DC naik dan turun tempat tidur. Semua hasil pembacaan dari sensor akan ditampilkan melalui LCD(Liquid Crystal Display). Pembacaan sensor pada alat ini mengacu pada titik acuan $\pm 3^{\circ}$ sebagai titik acuan $0^{o}$. Tempat tidur ini telah bekerja dengan baik sesuai dengan perancangan dengan bergerak naik turun berdasarkan nilai sudut untuk mencapai kondisi datar.
\end{abstract}

Kata kunci : Motor DC, Relay, Sensor Accelerometer Gyroscope, LCD

\begin{abstract}
The bed of Accelero Bed Control (ABC) patient is a patient bed that facilitates hospital to keep patient comfort and improve the quality of the hospital. This bed works on the slope of the hospital. This patient bed works by using the principles of a DC motor to raise and lower the bed, the gyroscope accelerometer sensor to detect the slope of the hospital, relay, and arduino microcontroller as its controller. The method used to make this tool was design. It works by reading accelerometer gyroscope sensors to detect slope lines at hospitals and relays as drivers to drive DC motor up and down the bed. All reading result from the sensor will be displayed via LCD (Liquid Crystal Display). The sensor reading in this tool refers to the reference point $\pm 3^{\circ}$ as a reference point of $0^{o}$. This bed has worked well appropriate with the design by moving up and down based on the angle value to achieve flat conditions.
\end{abstract}

Keywords： Motor DC, Relay, Sensor Accelerometer Gyroscope, LCD

\section{PENDAhUluan}

Pelayanan dasar merupakan hak bagi warga negara yang penyelenggaraan diwajibkan oleh peraturan perundangundangan, yang berarti pelayanan kesehatan menjadi urusan yang wajib pemerintahan daerah 1. pasca pemberlakuan kebijakan desentralisasi bidang kesehatan 2. Pelayanan kesehatan adalah pelayanan medik di Rumah Sakit Umum Daerah (RSUD) yang setiap anggota masyarakat berhak memperoleh pelayanan yang cepat, bermutu, mudah dan terjangkau sesuai standar pelayanan minimal (SPM)3 bidang kesehatan(Jurnal Manajeman Pelayanan Kesehatan,Volume 13 No4).

Salah satu upaya kuratif dan rehabilitatif yang dilakukan oleh rumah sakit yaitu dengan diselenggarakannya Unit
Rawat Inap (URI), yang bertujuan merawat pasien sakit dan memulihkan kesehatannya. Unit Rawat Inap (URI) disuatu rumah sakit memiliki peran penting dalam pengelolaan rumah sakit, hal ini dikarenakan sebagian besar pendapatan rumah sakit berasal dari pelayanan yang diberikan oleh Unit Rawat Inap (URI). Dalam pengelolaan Unit Rawat Inap (URI), salah satu aspek yang perlu diperhatikan adalah - pengelolaan tempat tidur pasien. Pengelolaan tempat tidur pasien perlu mendapat perhatian besar dari manajemen Rumah Sakit karena sebagai tempat perawatan pasien dan perlu diatur guna memperoleh efisiensi penggunaanya.Tempat tidur pasien adalah tempat tidur yang dibuat dan didesain khusus untuk mempermudah merawat dan sekaligus mengobati orang yang sedang sakit. Pada dasarnya tempat tidur untuk pasien yang berada di 
rumah sakit masih banyak yang berifat manual dan pada saat melewati jalur ramp atau miring pasien tidak berada pada posisi datar. Pelayanan rumah sakit untuk pasien merupakan hal yang perlu diprioritaskan sehingga perlu peralatan yang mampu mempermudah pasien sehingga pasien merasakan nyaman. Hal ini memberikan dampak kepercayaan pasien terhadap pihak rumah sakit.

Dari permasalahan diatas, peneliti akan membuat tempat tidur Accelero Bed Control (ABC) yang memudahkan intansi Rumah Sakit agar menjaga kenyamanan pasien dan meningkatkan kualitas mutu rumah sakit. Tempat tidur ini bekerja pada jalur ramp/miring tidak bergantung pada derajat jalur yang dilewati sehingga memberikan rasa kenyamanan pada pasien dan juga dapat membantu perawat dalam memberikan suatu pengobatan kepada pasien karena pasien yang kecelakaan harus pada posisi stabil/pada posisi yang tertentu. Dari permasalahan diatas alat ini dirancang untuk mempermudah proses menggerakkan tempat tidur, perancangan ini dibahas dalam tugas akhir yang berjudul "Rancang Bangun Tempat Tidur Pasien Otomatis Dengan Sensor Accelerometer Gyroscope Untuk Mengatur Keseimbangan Berbasis Mikrokontroler Arduino".

\section{STUDI PUSTAKA}

\section{A. Motor DC}

Motor Direct Current (DC) merupakan sebuah perangkat elektromagnetis yang mengubah energi listrik menjadi energi mekanik dimana desain awal terciptanya alat ini diperkenalkan oleh Michael Faraday

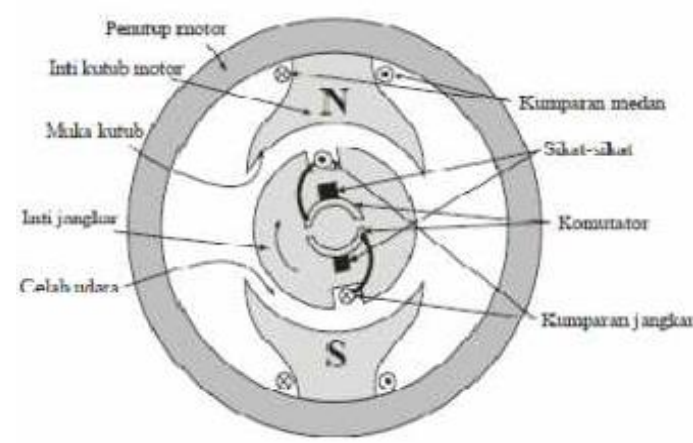

Gambar 1. Bagian-bagian mesin Direct Current (DC) (Sumber: Elga Nadzira Rengga,2012)

Prinsip dasar yang melatar belakangi kerja motor DC. Yang pertama yaitu adanya aliran arus yang melewati sebuah konduktor atau penghantar.Dimana,akan timbul

Medan magnet mengelilingi penghantar tersebut. Arah garis gaya magnet (fluks magnet) ini sesuai kaidah tangan kiri yang ditunjukan pada gambar 1. Ibu jari menandakan arah arus elektron yang mengalir dan jarijari menunjukan arah dari garis gaya magnet (fluks) yang mengelilingi penghantar.

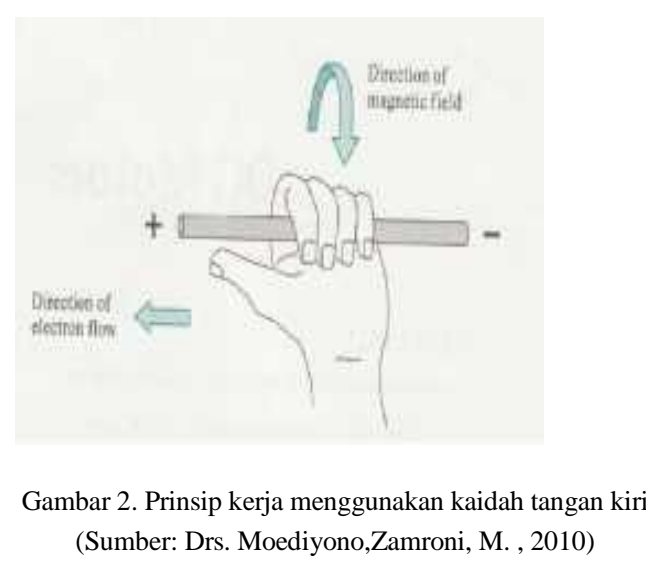

Yang kedua adalah gaya pada penghantar bergerak dalam medan magnet. Besarnya gaya yang didesakkan untuk menggerakkan berubah sebanding dengan kekuatan medan magnet, besarnya arus yang mengalir pada penghantar, dan panjang penghantar.gaya tersebut sering disebut gayaLorentz.

Sesuai dengan rumus:

$\mathrm{F}=\mathrm{B}$. I. 1 (Newton)

Dimana:

$\mathrm{F} \quad$ = Gaya pada kumparan(Newton)

B = Kuat medan $F$ magnet (Tesla)

I = Arus yang mengalir (Ampere)

$1=$ Panjang kumparan (meter)

Hubungan antara kecepatan, flux medan dan tegangan motor DC dalam persamaan berikut:

$\mathrm{E}=\mathrm{K} \varnothing \mathrm{n}$

$\mathrm{T}=\mathrm{K} \varnothing \mathrm{Ia}$

Keterangan:

$\mathrm{E} \quad$ = gaya elektromagnetik yang dikembangkan pada terminal dinamo (volt)

$\varnothing \quad=$ flux medan yang berbanding lurus dengan arus medan

$\mathrm{N}=$ kecepatan dalam rotation per minute (rpm)

$\mathrm{T}=$ torque elektromagnetik

$\mathrm{Ia}=$ arus dinamo

$\mathrm{K} \quad=$ konstanta persamaan

Hubungan daya dalam motor adalah sebagai berikut:

$V t I a=E I a+R a$

Keterangan:

VtIa = daya yang diberikan pada jangkar motor.

$I a^{2} \mathrm{Ra}=$ rugi-rugi motor

EIa = daya yang dihasilkan oleh jangkar

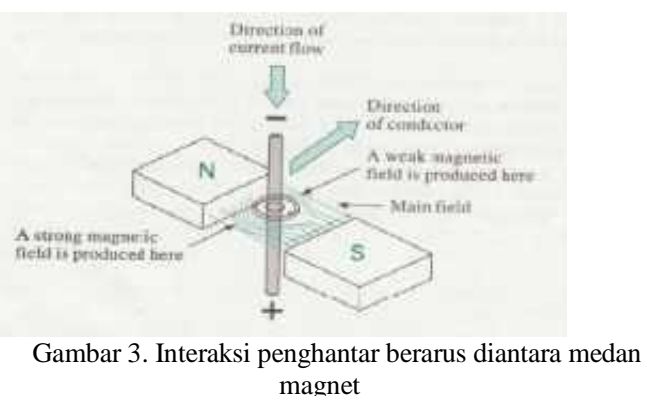


(Sumber: Drs. Moediyono,Zamroni, M. , 2010)

\section{B. Prinsip Kerja Motor DC}

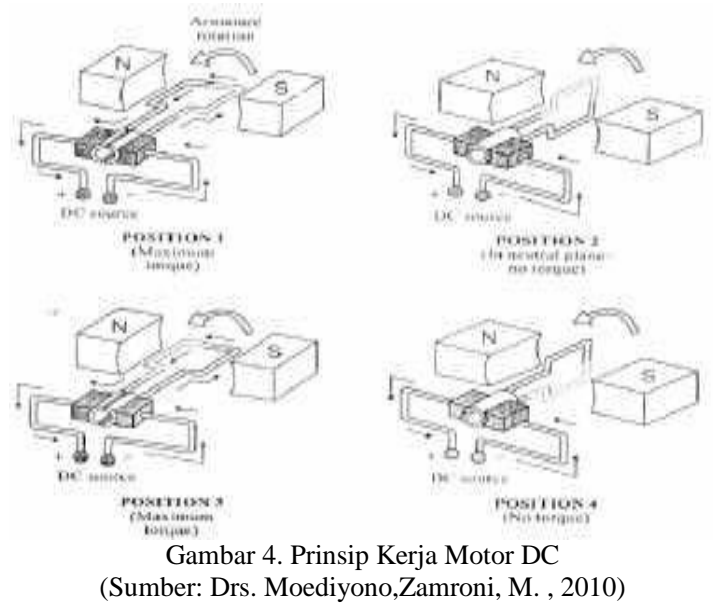

Arus mengalir melalui kumparan jangkar dari sumber tegangan dc, menyebabkan jangkar beraksi sebagai magnet. Gambar 3. menjelaskan prinsip kerja motor dc magnet permanent.

1. Pada posisi 1 arus electron mengalir dari sikat negative menuju ke sikat positif. Akan timbul torsi yang menyebabkan jangkar berputar berlawanan arah jarum jam. 2. Ketika jangkar pada posisi 2, sikat terhubung dengan kedua segmen komutator. Aliran arus pada jangkar terputus sehingga tidak ada torsi yang dihasilkan . Tetapi, kelembaman menyebabkan jangkar tetap berputar melewati titiknetral.

3, Pada posisi tiga letak sisi jangkar berkebalikan dari letak sisi 4 jangkar pada posisi 1 . Segmen komutator membalik arah arus elektron yang mengalir pada kumparan jangkar.Oleh karena itu arah arus yang mengalir pada kumparan jangkar sama dengan posisi 1.Torsi akan timbul yang menyebabkan jangkar tetap berputar berlawanan arah jarumjam. Jangkar berada pada titik netral. Karena adanya kelembaman pada poros jangkar, maka jangkar berputar terus-menerus.

\section{C.Putaran Motor DC}

Motor DC magnet permanent dapat berputar apabila ada arus yang mengalir pada kumparan jangkar sehingga menimbulkan fluks jangkar. Fluks jangkar tersebut berinteraksi dengan fluks magnet utama yang menghasilkan gaya untuk memutar jangkar (torsi). Arah dari putaran jangkar tersebut tergantung dari arah arus elektron yang mengalir pada kumparan jangkar. Poros motor dc dapat berputar searah jarum jam dan berlawanan arah jarum jam.Untuk menentukan arah putaran motor diperlihatkan pada gambar 4 tanda $(\mathrm{x})$ menunjukan arah arus electron yang menjauhi kita dan tanda $(\bullet)$ menunjukan arah arus electron yang mendekati kita. Tanda panah besar menunjukan arah putaran jangkar yang berlawanan arah jarum jam. Ketika posisi jangkar berada tegak lurus dengan fluks magnet utama, tidak ada reaksi, medan magnet antara fluks jangkar dengan fluks magnet utama. Karena moment inersia, putaran jangkar terus berlanjut.

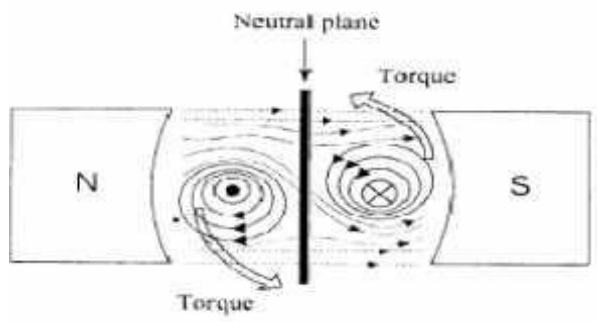

Gambar 5. Proses interaksi jangkar

(Sumber: Drs. Moediyono,Zamroni, M. , 2010

untuk putar berlawanan arah jarum jam Sedangkan untuk putaran motor dc searah jarum jam, arah arus elektron dibalik dengan cara mengubah polaritas sumber tegangan atau mengubah kutub pada ujung kumparan jangkar.

D.Arduino Uno R3

Arduino UNO adalah sebuah board mikrokontroler yang didasarkan pada ATmega328 (datasheet). Arduino UNO mempunyai 14 pin digital input/output (6 di antaranya dapat digunakan sebagai output PWM), 6 input analog, sebuah osilator Kristal $16 \mathrm{MHz}$, sebuah koneksi USB, sebuah power jack, sebuah ICSP header, dan sebuat tombol reset. Arduino UNO memuat semua yang dibutuhkan untuk menunjang mikrokontroler, mudah menghubungkannya ke sebuah computer dengan sebuah kabel USB atau mensuplainya dengan sebuah adaptor AC ke DC atau menggunakan baterai untuk memulainya.
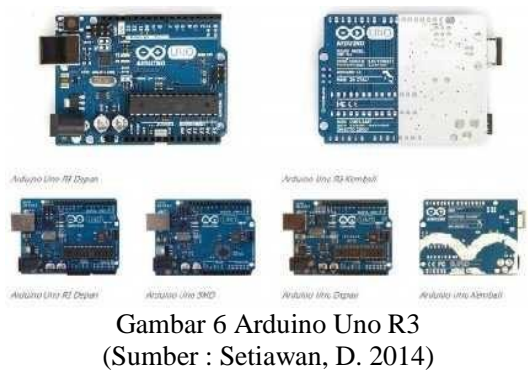

Tabel 1. Ringkasan Spesifikasi Arduino Uno R3 (Sumber: Setiawan,D. 2014)

\begin{tabular}{ll}
\hline Mikrokontroler & ATmega 328 \\
$\begin{array}{l}\text { Tegangan } \\
\text { Pengoperasian } \\
\text { Tegangan Input yang }\end{array}$ & $7-12 \mathrm{~V}$ \\
$\begin{array}{l}\text { Disarankan } \\
\text { Batas Tegangan Input }\end{array}$ & $6-20 \mathrm{~V}$ \\
Jumlah Pin I/O digital & $14(6$ diantaranya \\
& menyediakan keluaran PWM) \\
Jumlah pin Input Analog & 6 \\
Arus DC tiap pin I/O & $40 \mathrm{~mA}$ \\
Arus DC untuk pin 3.3V & $50 \mathrm{~mA}$ \\
Memori Flash & $32 \mathrm{~KB}$ (Atmega 328),sekitar \\
& 0,5 \\
SRAM & digunakan oleh bootloder \\
EEPROM & $2 \mathrm{~KB}($ Atmega 328) \\
Clock Speed & $1 \mathrm{~KB}($ Atmega 328) \\
\hline
\end{tabular}




\section{E.Pengertian Sensor}

Sensor adalah elemen sistem yang secara efektif berhubungan dengan proses dimana suatu variabel sedang diukur dan menghasilkan suatu keluaran dalam bentuk tertentu tergantung pada variabel masukannya, dan dapat digunakan oleh bagian sistem pengukuran yang lain untuk mengenali nilai variabel tersebut.

1. Proses Pengaturan Sistem Pada Sensor

Bagian ini merupakan elemen sistem instrumentasi yang akan mengambil keluaran dari sensor dan mengubahnya menjadi suatu bentuk besaran yang cocok untuk tampilan dan transmisi selanjutnya dalam beberapa sistem kontrol. Seperti pengondisi sinyal (signal conditioner) merupakan salah satu bentuk prosesor sinyal.

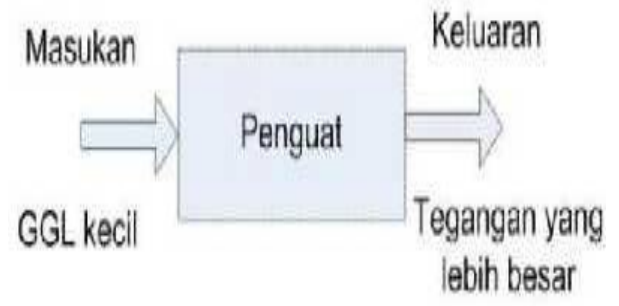

Gambar 7 Input Output Sistem Pengaturan (Sumber : Rafiudin Syam, 2013)

\section{Proses Penampilan Data}

Elemen terakhir pada sebuah sistem instrumentasi pengukuran adalah penampil data. Elemen ini menampilkan nilai-nilai yang terukur dalam bentuk yang bisa dikenali oleh pengamat, seperti melalui sebuah alat penampil (display), misalnya sebuah jarum penunjuk (pointer) yang bergerak disepanjang skala suatu alat ukur.

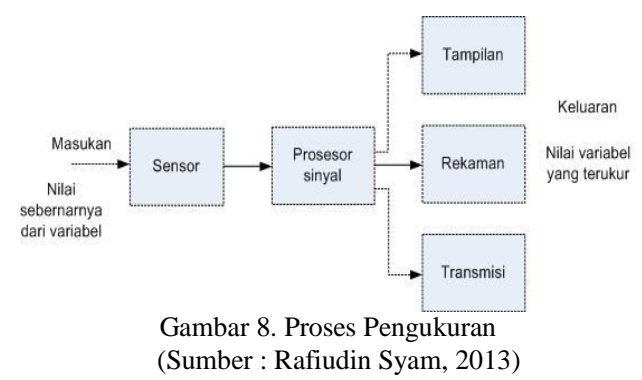

3. Sensor Accelerometer dan Gyroscope

Sensor Accelerometer Gyroscope biasa digunakan untuk membuat robot tetap seimbang. Mengetahui kemiringan, dan membantu bangunsaat robot terjatuh.

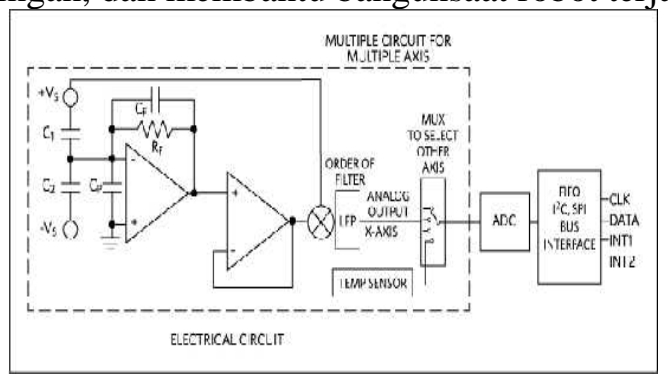

Gambar 8. Sirkuit Elektrik Accelerometer (Sumber : Majid Dadasfar, 2014)

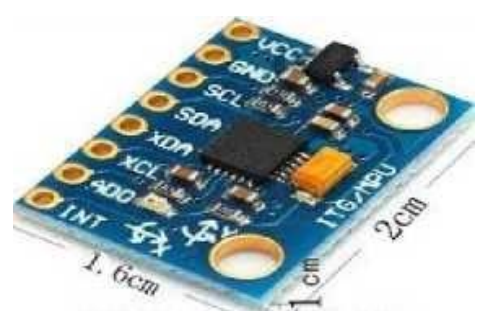

Gambar 9. Sensor Accelerometer dan gyroscope (Sumber : Rafiudin Syam, 2013)

\section{F. Relay}

Dalam dunia elektronika, relay dikenal sebagai komponen yang dapat mengimplementasikan logika switching.

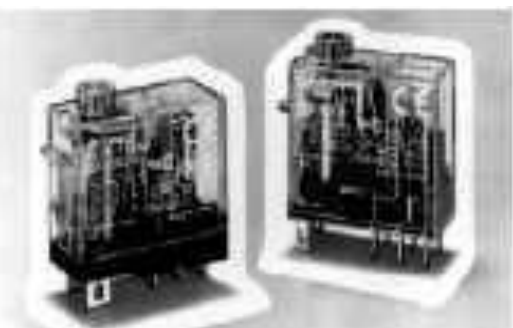

Gambar 10. Relay yang tersedia di pasaran (Sumber : Kilian, Christopher $\mathrm{T},: 1996)$

\section{Relay Modul 2 Channel}

Modul relay adalah saklar yang dioperasikan secara elektrik yang memungkinkan menghidupkan atau mematikan sirkuit dengan menggunakan voltase dan / atau arus yang jauh lebih tinggi daripada yang dapat ditangani oleh mikrokontroler.
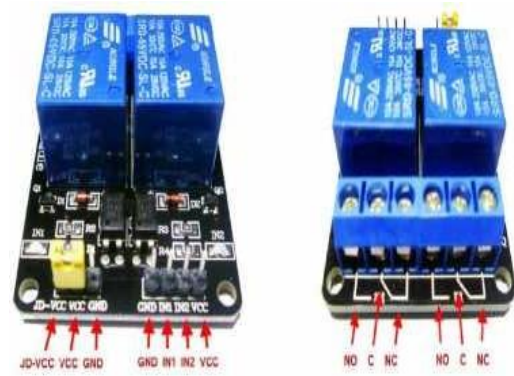

Gambar 11. Relay Modul 2 Channel tampak depan dan belakang (Sumber : Agustinus Pamungkas T. H. ,2017)

\section{G. LCD (Liquid Crystal Display)}

LCD merupakan singkatan dari Liquid Crystal Display, atau umumnya disebut dengan LCD atau display.

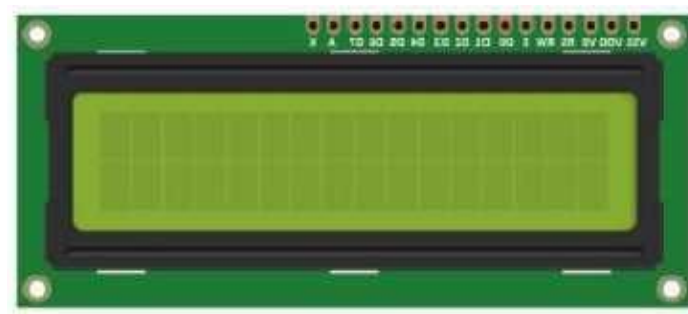

Gambar 12. Tampilan Liquid Crystal Display (Sumber : Hari Santoso, 2015) 
H. Struktur Jalur Ramp Rumah Sakit Kelas C (Sumber : Departement Kesehatan Republik Indonesia, 2007)

Ramp adalah jalur sirkulasi yang memiliki bidang dengan kemiringan tertentu, sebagai alternatif bagi orang yang tidak dapat menggunakan tangga.

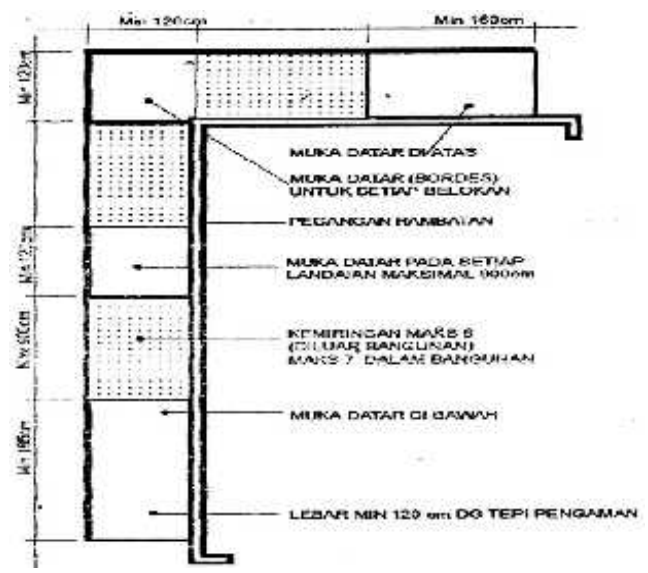

Gambar 13. Tipikal ramp

(Sumber : Departement Kesehatan Republik Indonesia, 2007)
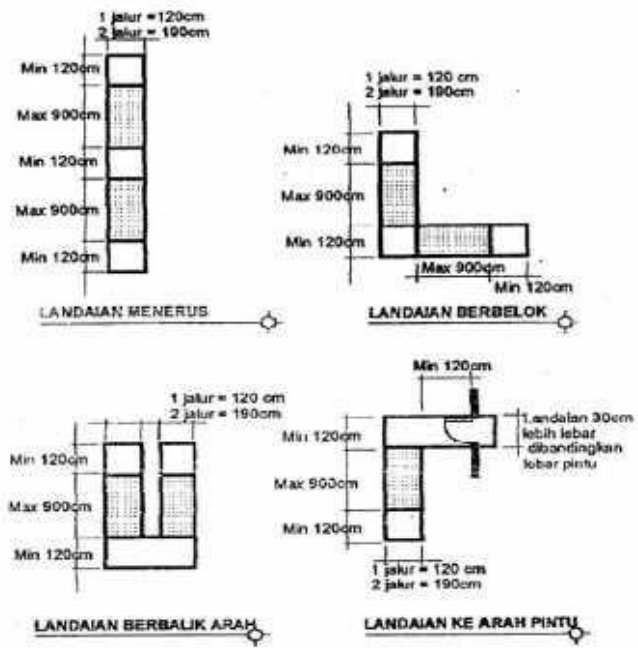

Gambar 14. Bentuk-bentuk ramp

(Sumber : Departement Kesehatan Republik Indonesia,2017)

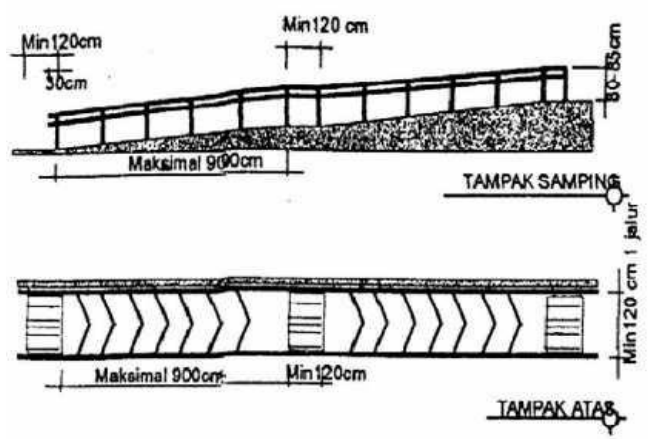

Gambar 15. Kemiringan ramp

(Sumber : Departement Kesehatan Republik Indonesia,2017)

\section{METODE}

\section{A. Identifikasi Masalah}

Langkah awal sebelum melakukan penelitian adalah mengidentifikasi masalah atau perumusan masalah yang akan diteliti dengan terlebih dahulu melakukan survey atau pra penelitian dengan cara melakukan survey di rumah sakit dan melakukan pengamatan pada objek penelitian. Dan hasil penelitian inilah dapat didefinisikan masalah yang dihadapi perusahaan tersebut yang sesuai dengan masalah yang akan dihadapi oleh intansi rumah sakit tersebut dengan peningkatan kualitias kenyaman terhadap pasien.

\section{B. Menetapkan Tujuan Penelitian}

Menciptakan tujuan penelitian merupakan langkah yang harus dilakukan. Hal inilah dilakukan dengan maksud untuk menghindari terjadinya penyimpangan antara tujuan yang ingin dicapai dengan hasil yang didapatkan.

\section{Diagram Alur Penyelesaian masalah}

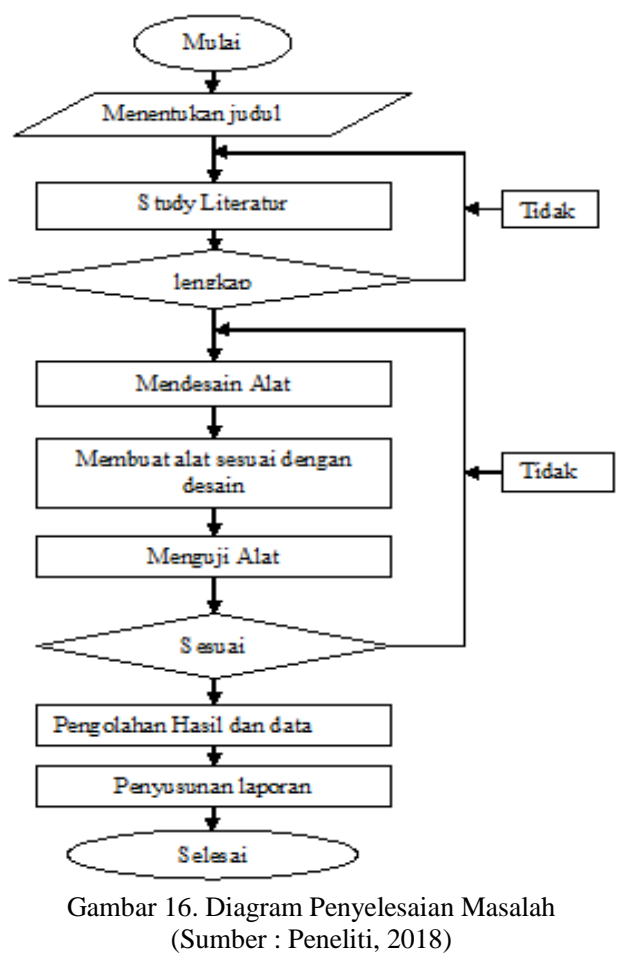




\section{Skema Diagram Sistem}

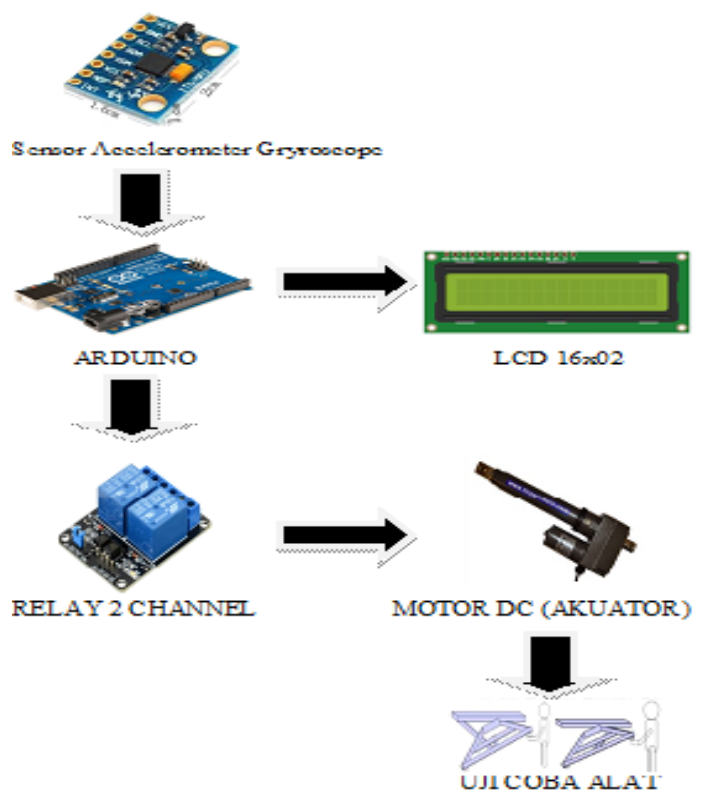

Gambar 17. Blok Diagram Hardware (Sumber : Peneliti, 2018)

\section{E. Desain Perencanaan Tempat Tempat Tidur}

Desain model tempat tidur otomatis berbasis accelerometer gyroscope.

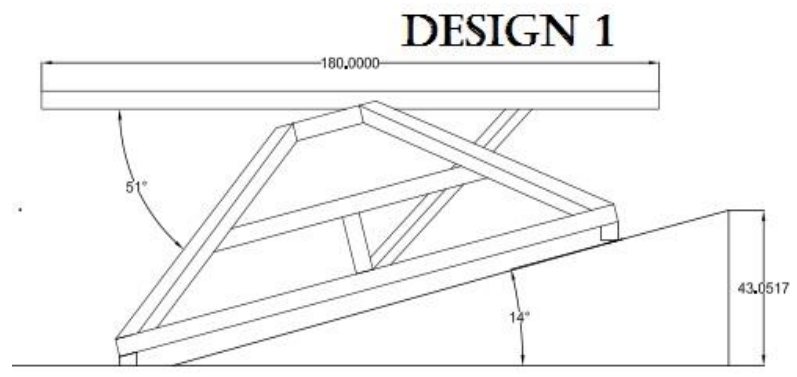

Gambar 18. Rancangan Tempat tidur pada saat posisi miring (Naik) (Sumber: Peneliti, 2018)

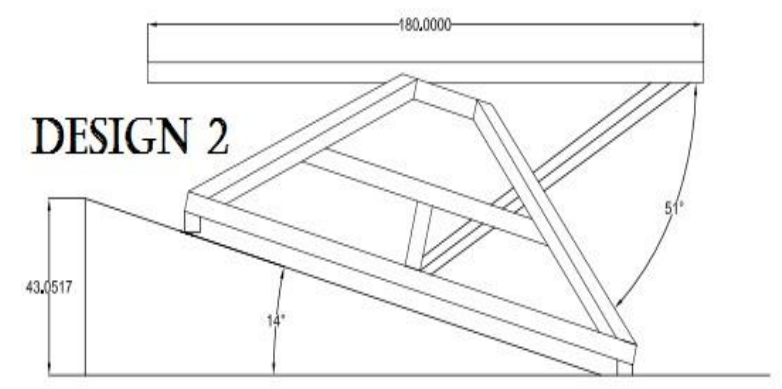

Gambar 19. Tempat tidur pada saat posisi miring (Turun) (Sumber: Peneliti, 2018)

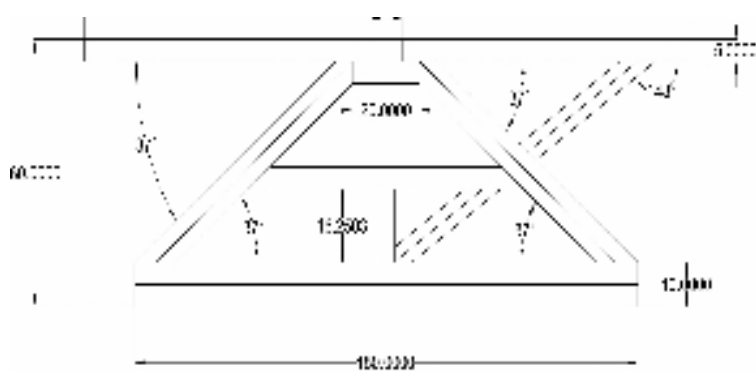

Gambar 20. Tempat tidur pada saat posisi miring (Datar) (Sumber: Peneliti, 2018)

\section{ANALISA DAN PEMBAHASAN}

\section{A.Konfigurasi Sistem Kinerja Alat}

Konfigurasi sistem yang digunakan pada proyek akhir ini secara umum terdiri dari dua bagian dasar, yaitu perangkat keras (hardware) dan perangkat lunak (software)

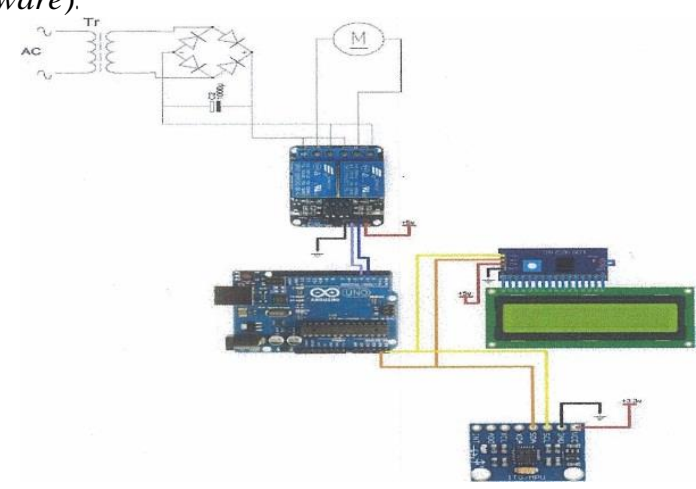

Gambar 21. Konfigurasi Kinerja Sistem Alat (Sumber: Peneliti, 2018)

Pada perancangan ini menggunakan penurun tegangan AC, yaitu power supply 220 volt AC ke 36 volt DC sebagai penggerak motor DC dan 9 volt sebagai catu daya arduino UNO R3

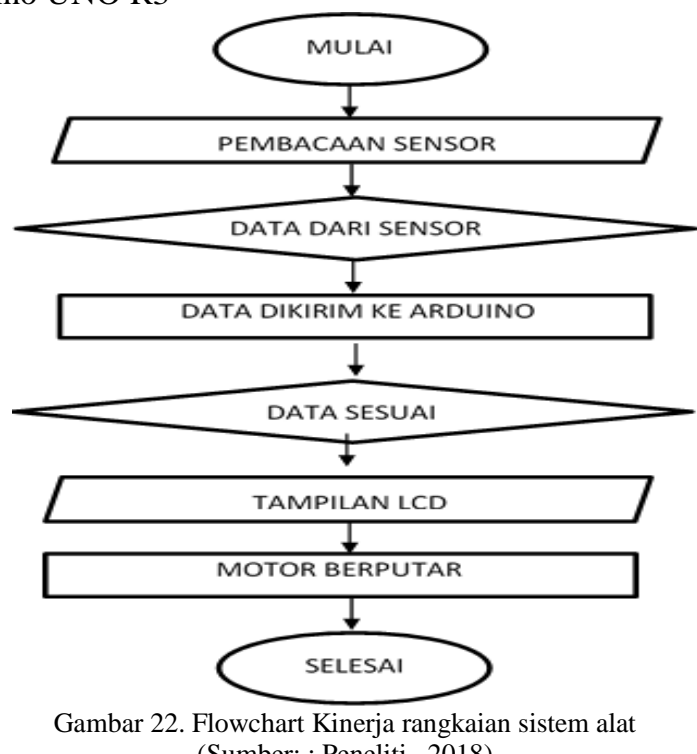

(Sumber: : Peneliti, 2018)

Table 2 adalah basil pengukuran tegangan pada setiap perangkat yang digunakan. Nilai-nilai yang didapat adalah 
nilai-nilai yang paling banyak muncul pada alat ukur multimeter.

Tabel 2. Data Pengujian Komponen (Sumber : Peneliti, 2018)

\section{VARIABEL}

TEGANGAN

\begin{tabular}{ll}
\hline POWER SUPPLY MOTOR DC & 36 Volt \\
MOTOR DC & 36 Volt \\
ARDUINO UNO R3 & 5 Volt \\
I2C LCD ADAFRUIT & 5 Volt \\
RELAY MODUL 2 CHANNEL & 5 Volt \\
SENSOR MPU 6050 & 3,3 Volt \\
\hline
\end{tabular}

B. Pengujian Sensor Accelerometer dan Gyroscope (MPU6050)

Pengujian ini dilakukan untuk mengetahui nilai yang diukur oleh sensor MPU6050 sehingga dapat mengetahui nilai real yang terukur dibandingkan dengan nilai busur derajat yang diukur. Banyaknya pengujian yang dilakukan adalah enam kali, karena dengan melakukan enam kali pengujian dapat mewakili isi keseluruhan data.

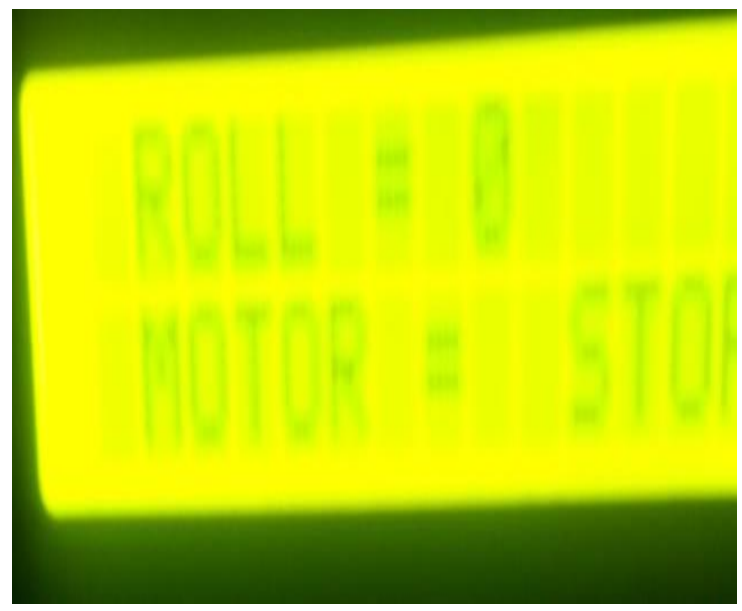

Gambar 22 Pengujian Sensor (kondisi stop) (Sumber : Peneliti,2018)

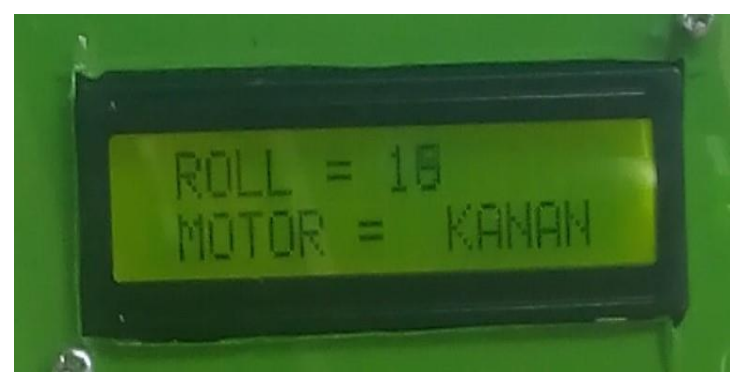

Gambar 23. Pengujian Sensor (Motor Bergerak) (Sumber : Peneliti,2018)

\section{B. Nilai Roll Pada Sensor MPU 6050}

Berikut ini adalah gambar alat pengujian sensor MPU6050 untuk nilai roll dibandingkan dengan nilai busur derajat yang terukur.
Tabel 3. Pengujian Nilai Sensot (Sumber : Peneliti, 2018)

\begin{tabular}{|l|l|l|l|l|l|l|l|l|}
\hline Nilai & \multicolumn{9}{|l|}{ Pengujian Nilai Sensor } & Nilai & Nilai \\
\cline { 2 - 8 } Busur & 1 & 2 & 3 & 4 & 5 & 6 & Rata -rata & Error \\
\hline $10^{\circ}$ & $10^{\circ}$ & $10^{\circ}$ & $11^{\circ}$ & $10^{\circ}$ & $10^{\circ}$ & $10^{\circ}$ & $10,1^{\circ}$ & 0,16 \\
\hline $30^{\circ}$ & $30^{\circ}$ & $31^{\circ}$ & $30^{\circ}$ & $29^{\circ}$ & $30^{\circ}$ & $30^{\circ}$ & $30^{\circ}$ & 0 \\
\hline $40^{\circ}$ & $40^{\circ}$ & $41^{\circ}$ & $40^{\circ}$ & $40^{\circ}$ & $40^{\circ}$ & $40^{\circ}$ & $4,16^{\circ}$ & 0,16 \\
\hline $60^{\circ}$ & $60^{\circ}$ & $60^{\circ}$ & $61^{\circ}$ & $60^{\circ}$ & $60^{\circ}$ & $59^{\circ}$ & 60 & 0 \\
\hline $90^{\circ}$ & $90^{\circ}$ & $90^{\circ}$ & $89^{\circ}$ & $90^{\circ}$ & $91^{\circ}$ & $91^{\circ}$ & 90,16 & 0,16 \\
\hline $120^{\circ}$ & $120^{\circ}$ & $119^{\circ}$ & $121^{\circ}$ & $120^{\circ}$ & $121^{\circ}$ & $120^{\circ}$ & 120,16 & 0.16 \\
\hline $160^{\circ}$ & $159^{\circ}$ & $160^{\circ}$ & $162^{\circ}$ & $161^{\circ}$ & $160^{\circ}$ & $161^{\circ}$ & 160,5 & 0,5 \\
\hline $180^{\circ}$ & $179^{\circ}$ & $180^{\circ}$ & $180^{\circ}$ & $180^{\circ}$ & $181^{\circ}$ & $180^{\circ}$ & 180 & 0 \\
\hline
\end{tabular}

Data yang diperoleh dari hasil pengujian, menunjukkan bahwa terdapat beberapa perbedaan nilai sensor dan busur. Dalam enam kali berikut

1. Penghitungan nilai sensor dengan busur $10^{\circ}$ Nilai rata-rata $=\frac{10+10+11+10+10+10}{6}=10,1$ Error $=$ $10,16-10=0,16$

2. Penghitungan nilai sensor dengan busur $30^{\circ}$ Nilai rata-rata $=\frac{30+30+30+30+30+30}{6}=30$ Error $=30-$ $30=0$

3. Penghitungan nilai sensor dengan busur $40^{\circ}$ Nilai

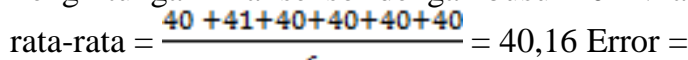
$40,16-40=0,16$

4. Penghitungan nilai sensor dengan busur $60^{\circ}$ Nilai rata-rata $=\frac{60+60+61+60+60+59}{6}=60$ Error $=60-$ $60=0$

5. Penghitungan nilai sensor dengan busur $90^{\circ}$ Nilai $90+90+89+90+91+91$

rata-rata $=6 \quad=60$ Error $=90-$ $90,16=0,16$

6. Penghitungan nilai sensor dengan busur $120^{\circ}$ Nilai $120+119+120+120+121+120$ rata-rata $=\frac{6}{6}=721$ Error $=120,16-0,16=0,16$

7. Penghitungan nilai sensor dengan busur $60^{\circ}$ $159+160+162+161+60+161$

Nilai rata-rata $=\frac{6}{6}=963$

Error $=160,5-160=0,5$

8. Penghitungan nilai sensor dengan busur $60^{\circ}$ Nilai $179+180+180+180+181+180$

rata-rata $=6 \quad=180$ Error
$=180-180=0$ 


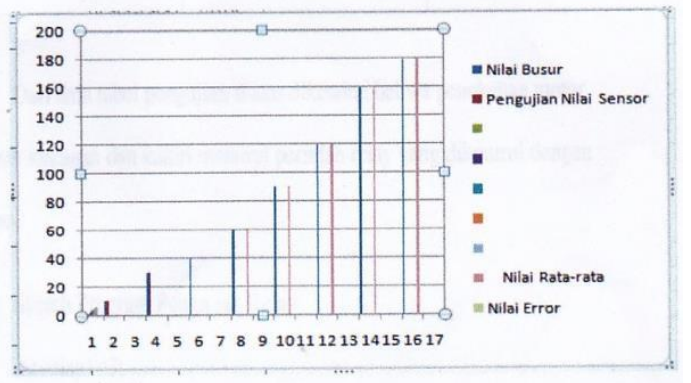

Gambar 24. Grafik Pengujian Nilai Sensor (Sumber : Peneliti, 2018)

\section{Pengujian Relay}

Pengujian ini dilakukan dengan memberikan logika high atau low pada pin relay yaitu pada pin 3 dan 4 basil pengujian relay dapat dilihat pada tabel 4

Tabel 4. Tabel Pengujian Relay

\begin{tabular}{|c|c|c|}
\hline \multirow{2}{*}{$\begin{array}{c}\text { RELAY I } \\
\text { (LOGIKA) }\end{array}$} & \multirow{2}{*}{$\begin{array}{c}\text { RELAY 2 } \\
\text { (LOGIKA) }\end{array}$} & OUTPUT \\
\cline { 3 - 3 } & & RELAY \\
\hline 1 & 1 & 1 \\
\hline 1 & 0 & 1 \\
\hline 0 & 1 & 1 \\
\hline 0 & 0 & 0 \\
\hline
\end{tabular}

\section{Pengujian Motor DC}

Pengujian relay dengan Motor DC dilakuan dengn melihat tabel kebenaran dari driver relay. Tabel 5 Pengujian Motor DC.

Tabel 5. Tabel Pengujian Motor DC

\begin{tabular}{lll}
\hline RELAYl & RELAY2 & RESPONSE MOTOR \\
\hline MATI & MATI & MATI \\
HIDUP & MATI & BERPUTAR KANAN \\
MATI & HIDUP & BERPUTAR KIRI \\
HIDUP & HIDUP & MOTOR MATI RELAY MENYALA
\end{tabular}

\section{E. Pengujian Data Keseluruhan}

Tabel 6. Tabel Pengujian Nilai Sensor, Relay, dan Motor

\begin{tabular}{ll}
\hline SUDUT & RESPONSE MOTOR \\
& PADA RANJANG \\
\hline$-20^{\circ}$ & TURUN \\
$-10^{\circ}$ & TURUN \\
$-3^{\circ}$ & TURUN \\
$0^{\circ}$ & DIAM \\
$3^{\circ}$ & NAIK \\
$10^{\circ}$ & NAIK \\
$20^{\circ}$ & NAIK \\
\hline
\end{tabular}

Didalam pengujian keseluruhan alat diberikan nilai antara -3 sampai dengan +3 untuk memberikan nilai threshold sebagai parameter untuk menggerakkan motor bekerja.

\section{KESIMPULAN}

\section{A. Kesimpulan}

Dari hasil perancangan clan pengujian yang telah dilaksanakan dalam penelitian "Perancangan Alat Tempat tidur pasien berbasis mikrokontroler arduino dan sensor accelerometer gyroscope", dapat diambil beberapa kesimpulan, diantaranya:

1. Tempat tidur otomatis telah bekerja dengan baik sesuai perancangan dengan bergerak naik dan turun berdasarkan nilai sudut untuk mencapai kondisi datar.

2. Tempat Tidur ini dirancang dengan menggunakan sensor accelorometer dan gyroscope untuk mencapai sudut $\mathrm{O}$ derajat sebagai parameter tempat tidur pada posisi datar dengan menggunakan relay dan mikrontroler arduino.

\section{B. Saran}

Berdasarkan hasil penelitian ini, diperoleh beberapa saran sebagai berikut:

1. Untuk penelitian selanjutnya dapat ditambahkan metode tambahan agar ranjang dapat dikendalikan dengan android.

2. Alat ini dapat dikembangkan dengan menggunakan metode pengendalian seperti PID/Fuzzy untuk lebih menghaluskan gerakan Motor DC.

3. Hasil Kinerja Sensor Masih kurang maksimal dan karena pada saat terjadi guncangan posisi sudah tidak stabil,penulis mengharapkan masukkan.

\section{REFERENS}

[1] Graham, Brian B. 2000. Using an Accelerometer Sensor To Measure Human Hand Motion. Departement of Electrical Engginering and Computer Science. Massachussetts Institute Of Technology. Massachutts

[2] Sung,Woon-T.,Kang,T.,Lee,J.G.,.2008. Controler Design of a MEMS Gyro-Accelerometer with a Single Proof Mass. International Journal Of Control, Automation, and System.Vol. 6. No. 6

[3] Kissel,Thomas E. 1990. Modern Industrial Electrical Motorcontrols. Prentice-Hall: New Jersey

[4] Arsyad, M. Lukman. 2010. Bed Occupantion Of District General Hospital After Health Policy Dezentralization South Sulawesi. Jurnal Manajemen Kesehatan. Vol. 13 No. 04

[5] Dadasfar, Majid. 2014. Accelerometer Dan Gyroscope Sensor Operasi,Penginderaan dan Aplikasi. Maxim Integrated Products, Inc.

[6] Elga, Nadzira R. 2013. Perancangan Alat Pengaduk Tepung adonan bakery menggunakan Motor DC $1 / 2$ HP dengan kontroler PID. Jember : Universitas Jember

[7] Syam, Rafiuddin. 2013. Seri Buku Ajar Dasar Dasar Teknik Sensor. Makassar: Universitas Hassanudin

[8] Pusat Sarana, Prasarana dan Peralatan Kesehatan. 2007. Pedoman Teknis Sarana dan Prasarana Rumah sakit Kelas C. Departemen Kesehatan Republik Indonesia

[9] Pamungkas, Agustinus. 2017. Pengering Otomatis Berbasis Arduino Uno. Yogyakarta: Universitas Sanata Dharma.

[10] Satria, Bagus. 2010. Rancang Bangun Tempat Tidur Pasien Dengan Perbandingan Sudut Terakhir. Surabaya : Politeknik Elektronika Negeri Surabaya. 